\title{
Cancer-Testis Antigen Family 45 Gene
}

National Cancer Institute

\section{Source}

National Cancer Institute. Cancer-Testis Antigen Family 45 Gene. NCI Thesaurus. Code C129433.

A family of genes that is comprised of nine protein coding genes and one pseudogene, which are nearly identical in sequence and are clustered in the vicinity of Xq26.3. 